\title{
C-C Motif Chemokine 5
}

National Cancer Institute

\section{Source}

National Cancer Institute. C-C Motif Chemokine 5. NCI Thesaurus. Code C20483.

C-C motif chemokine 5 (91 aa, $\sim 10 \mathrm{kDa}$ ) is encoded by the human CCL5 gene. This protein plays a role in both the release of histamine and chemoattraction of monocytes, memory T-helper cells and eosinophils. 